\title{
The effect of moisture content and temperature on spore aging in Osmunda regalis
}

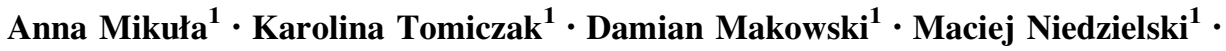 \\ Jan J. Rybczyński ${ }^{1}$
}

Received: 6 March 2015/Revised: 17 June 2015/Accepted: 5 October 2015/Published online: 14 October 2015

(c) The Author(s) 2015. This article is published with open access at Springerlink.com

\begin{abstract}
For spores, like seeds, the moisture level and storage temperature seem to be crucial factors responsible for their survival. However, in chlorophyllous spores in particular, the problem is not yet fully understood. The aim of this study was to investigate the effect of moisture content (MC; 6.6 and $4.6 \%)$ and storage temperature (15 and $-196^{\circ} \mathrm{C}$ ) on spore germination and gametophyte development in Osmunda regalis. The MC (fresh weight basis) in freshly released spores was $7.5 \%$, and decreased to 6.6 and $4.6 \%$ during 2 weeks of spore storage at 42 and $18 \%$ relative humidity, respectively. Those spores germinated at $99.9 \%$ within $28 \mathrm{~h}$. The spores with 6.6 and $4.6 \%$ $\mathrm{MC}$ were used for the storage at 15 and $-196^{\circ} \mathrm{C}$. The deterioration of spores, maintained with $6.6 \% \mathrm{MC}$, proceeds within 1.5 years of storage at $15{ }^{\circ} \mathrm{C}$, starting with month 8 . For the spores with $4.6 \% \mathrm{MC}$ serious disturbances in germination and capacity to gametophyte development were postponed for more than 6 months. The time required for spore germination increased with the age of the spores, ranging from $28 \mathrm{~h}$ in fresh spores to 10 days in spores stored for more than 11 months. Following 7-year-long cryostorage, spore viability remained at $99.9 \%$, the time taken for germination remained unaltered and gametophyte development was normal. The viability and vigor of spores were directly correlated with their age, the moisture content and storage temperature.
\end{abstract}

Communicated by M. Lambardi.

Anna Mikuła

amikula@obpan.pl

1 Polish Academy of Sciences Botanical Garden - Center for Biological Diversity Conservation in Powsin, Prawdziwka 2, 02-973 Warsaw, Poland
Keywords Germination · Liquid nitrogen · Long-term cryostorage $\cdot$ Spore equilibrium relative humidity

$\begin{array}{ll}\text { Abbreviations } \\ \text { eRH } & \text { Equilibrium relative humidity of spores } \\ \text { LN } & \text { Liquid nitrogen } \\ \text { MC } & \text { Moisture content } \\ \text { RH } & \text { Air relative humidity }\end{array}$

\section{Introduction}

Ferns are an important component of the ecosystem and are among those plants whose genetic diversity often becomes extremely narrow, thus leading to a potentially higher risk of extinction. The royal fern (Osmunda regalis L., Osmundaceae) is one such plant. O. regalis is a sub-cosmopolitan species, with a sub-Atlantic distribution in Europe. It also occurs around the Mediterranean basin, in southern Africa, America, Asia, and New Zealand (IUCN 2014). The species is declining in many parts of Europe and has become rare or threatened with extinction as a result of wetland drainage, forest clearance and habitat destruction due to agriculture. According to the International Union for Conservation of Nature and Natural Resources (IUCN 2014), O. regalis is included in the national Red Lists of many countries including Poland (Mirek et al. 2006).

Over the last decade, the importance of fern preservation has been considered more seriously (Quintanilla et al. 2002; Pence 2008a, b; Li et al. 2010; Barnicoat et al. 2011; Ballesteros 2011; Gabriel y Galán and Prada 2011; Ibars and Estrelles 2012; Li and Shi 2014, 2015). Among those 
discussed, species belonging to the family Osmundaceae takes a special place. Soil spore-banks do not play a very important role in the conservation of these species owing to the inability of their spores to survive long periods under wet conditions (Ibars and Estrelles 2012; Gupta et al. 2013). Consequently, several ex situ conservation methods have been studied for Osmunda spp., including recovery of viable germplasm from herbarium specimens (Magrini et al. 2010), in vitro propagation (Morini 2000; Soare 2008), gametophyte banking with cryopreservation (Mikuła et al. 2011), and spore banking under various storage temperature conditions (Pence 2000; Ballesteros et al. 2011; Magrini and Scoppola 2012; Li and Shi 2014, 2015)

Species belonging to Osmundaceae are one of those ferns that produce chlorophyllous (green, photosynthetic) spores (Lloyd and Klekowski 1970). Such spores not only germinate faster than their non-chlorophyllous (non-green) counterparts, but also lose their viability very quickly. Green spores exhibit a tendency to germinate 1 or 2 days after sowing, and their average viability is only 48 days (Lloyd and Klekowski 1970; Windham et al. 1986). The results of previous life-span studies of $O$. regalis spores vary greatly. For example, it was shown that spores stored without any pre-treatment at 25 or 15 or $5{ }^{\circ} \mathrm{C}$ retained their capacity to germinate at about $3 \%$ for only 1 month (Magrini and Scoppola 2012). On the other hand, about $5 \%$ viability was reported for $O$. regalis spores maintained for 3.5 years at $4{ }^{\circ} \mathrm{C}$ (Stokey 1951). Furthermore, Magrini et al. (2010) showed that $2 \%$ of $O$. regalis spores was capable of germination and subsequently developing into gametophyte even after 5 years of storage in a herbarium. Li and Shi $(2014,2015)$ paid attention to that the viability of $O$. japonica spores can be affected not only by extending the storage period and temperature conditions, but also by the moisture content of the spores. These authors first reported evidence of the effect of water content of green spores before and after desiccation on their germination ability.

The storage of fern spores in liquid nitrogen (LN) appears to be the most appropriate for the maintenance of fern species. However, our knowledge of spore viability, especially those ephemeral, during long-term LN protection is still poor. A few reports devoted to this problem showed that the viability of $O$. regalis and $O$. japonica green spores could be successfully maintained for at least 12 (Li and Shi 2014, 2015), 18 (Pence 2000) and even 24 months (Ballesteros et al. 2011) in LN storage. In contradiction, the non-green spores of three fern species, i.e. Pteris sp., Cyrtomium falcatum and Polystichium tsussinense, were capable of germination after 75 months of storage at $-196{ }^{\circ} \mathrm{C}$ (Pence 2000). However, the studies of Ballesteros et al. (2011) showed that LN storage prolonged viability of Equisetum ramosissimum green spores effectively for only 1 year. After that time, a serious decline in spore viability was observed. It was shown that 1 -year-long cryostorage of non-green spores of Alsophila spinulosa and A. gigantea resulted in a comparatively small loss of viability, but for this period, the viability of ephemeral spores of A. podophylla was lost ( $\mathrm{Li}$ et al. 2010). This indicates that the monitoring of spore viability during their long-term storage in LN is absolutely essential.

Chlorophyllous spores are the object of not only ex situ conservation programmes, but also of physiological investigations as short-living, yet quickly deteriorating, unique plant material. It seems that the main factors affecting spore viability during storage, i.e. moisture and storage temperature, are similar to those described for seeds. However, there is still so little known about the effect of moisture content on green spore viability and also about the decline in their vigor. The aim of this study was to investigate the effect of moisture content and storage temperature on spore germination and gametophyte development in $O$. regalis.

\section{Materials and methods}

\section{Plant material}

Mature fertile fronds of $O$. regalis, green at the top and cinnamon-colored at the bottom, were collected at the end of May at Polish Academy of Sciences Botanical GardenCBDC field collection. The experiments were started in 2008. Freshly collected fronds were stored in a paper envelope for 2 days at ambient room conditions $\left(24 \pm 5{ }^{\circ} \mathrm{C}\right.$; RH ca. $\left.45-80 \%\right)$ until the sporangia dehisced and spores were released. For spore cleaning, a sieve of mesh size $100 \mu \mathrm{m}$ was used. The spores were kept in darkness, in a climatic chamber at controlled temperature of $25 \pm 1{ }^{\circ} \mathrm{C}$, and under two different relative humidity conditions: $42 \pm 2$ or $18 \pm 2 \%$ for 2 weeks. The equilibrium relative humidity of spores (eRH) and their moisture content (MC) were determined (Table 1). These spores were used for experiments as a control.

\section{Spore storage conditions}

Samples of spores with two various initial moisture levels were placed in the dark, in two storage environments:

1. A climatic chamber with controlled temperature $\left(15 \pm 1{ }^{\circ} \mathrm{C}\right)$ and a relative humidity (RH) of $18 \pm 2 \%$;

Spores which were initially kept for 2 weeks at $42 \pm 2 \% \quad \mathrm{RH}$ were stored in a very tight 
Table 1 Changes in an equilibrium relative humidity (eRH) and moisture content (MC) of $O$. regalis spores equilibrated with air

\begin{tabular}{|c|c|c|c|}
\hline Storage conditions of spores & $\begin{array}{l}\text { Time of measurement } \\
\text { (after spore collected) }\end{array}$ & eRH spores $(\%)$ & Spore $\mathrm{MC}(\%)$ \\
\hline Environmental conditions & Immediately & $69.8 \pm 5$ & - \\
\hline \multicolumn{4}{|c|}{ Ambient room conditions $\left(24 \pm 5{ }^{\circ} \mathrm{C}\right)$} \\
\hline \multirow[t]{2}{*}{ RH ca. $45-80 \%$} & $24 \mathrm{~h}$ & $54.7 \pm 3$ & - \\
\hline & $48 \mathrm{~h}$ & $48.6 \pm 2$ & $7.5 \pm 0.02$ \\
\hline \multicolumn{4}{|l|}{ Climatic chamber $\left(25 \pm 1^{\circ} \mathrm{C}\right)$} \\
\hline $\mathrm{RH} 42.0 \pm 2 \%$ & 2 weeks & $41.0 \pm 2$ & $6.6 \pm 0.05$ \\
\hline $\mathrm{RH} 18.0 \pm 2 \%$ & & $18.5 \pm 2$ & $4.6 \pm 0.03$ \\
\hline \multicolumn{4}{|c|}{ Climatic chamber $\left(15 \pm 1{ }^{\circ} \mathrm{C}\right): \mathrm{RH} 18.0 \pm 2 \%$} \\
\hline In a tightly closed vials & 18 months & $39.4 \pm 1$ & $5.9 \pm 0.05$ \\
\hline In open Petri dishes & & $16.9 \pm 0.5$ & $4.5 \pm 0.03$ \\
\hline
\end{tabular}

polypropylene vials $(10 \mathrm{ml})$ with screw cap and rubber seal. The vials were opened for $1-2 \mathrm{~s}$ every 2 weeks for exchange of gases. The second spore samples, which were initially kept at $18 \pm 2 \% \mathrm{RH}$, were stored in open Petri dishes.

The eRH of both type of spores was measured every month during the time of their storage. The final values of eRH of spores after 18 months of storage are shown in the last line of Table 1.

2. Liquid nitrogen $\left(-196{ }^{\circ} \mathrm{C}\right)$.

For those samples to be stored at a temperature of $-196{ }^{\circ} \mathrm{C}$, the $2 \mathrm{ml}$ polypropylene cryovials, each containing about $0.1 \mathrm{ml}$ of freshly collected spores, were directly immersed in LN. Spores were thawed quickly by placing the cryovials in a $38{ }^{\circ} \mathrm{C}$ water bath for 3 min (Mikuła et al. 2009).

\section{Viability assays}

The spore ability to germinate (germinability), the time of germination and the ability of germinated spores to develop into gametophytes were assessed for both storage conditions and moisture tested. The tests were performed every month, on un-disinfected spores sown in sterile, distilled water $(5 \mathrm{ml})$ in glass Petri dishes $(9 \mathrm{~cm}$ in diameter). For samples stored at a temperature $-196{ }^{\circ} \mathrm{C}$ more than 2 years, the viability tests were carried out every year. Germination was performed in a climatic chamber at $22 \pm 2{ }^{\circ} \mathrm{C}$ with a 16 -h photoperiod of light intensity $50 \mu \mathrm{M} \mathrm{m}^{-2} \mathrm{~s}^{-1}$.

All spores, whether live or dead, were counted by scoring 16 fields of vision under a light microscope using 3 independent replicates for each storage time and storage condition (at least 600 spores per replicate). An ability to germinate was calculated as the ratio of germinating spores to the total spores scored and expressed as a percentage. Spores were considered to be germinated when their cell wall was ruptured and at least one cell division happened. A detection of germinated spores was carried out with the help of an epifluorescence microscope (Vanox AHBT3, Olympus, Japan) equipped with computer image analysis system (cellSens Standard ver. 1.7). Fluorescence was induced by blue-violet light (BV filter $400-440 \mathrm{~nm}$ ).

Time of germination was expressed as the minimum time required for germination of all living spores. The number of gametophytes emerging daily was counted from the day of planting the spores onto the film of water till the time the spore germination was completed. Spores were examined using an epifluorescence microscope.

The ability of germinated spores to develop into gametophytes was assessed starting from the first day of spore germination until the time the development of gametophytes was advanced. Gametophyte development was expressed as a percentage of spores that developed into gametophytes over the total number of spores germinated.

\section{Monitoring of spore moisture status}

For monitoring of spore moisture status, the rapid and nondestructive method of equilibrium relative humidity (eRH) assessment was used (Probert et al. 2003). The relative humidity $(\mathrm{RH})$ of the air at equilibrium with spores held in a sealed chamber of a hygrometer was measured at a prescribed temperature of $+21 \pm 2{ }^{\circ} \mathrm{C}$ by means of a digital humidity sensor Hygrolab with probe AW-DIO (Rotronic $\mathrm{AG})$. The $\mathrm{eRH}$ of spores was determined every $24 \mathrm{~h}$ for the first 2 days (i.e. until all spores from sporangia were released), and next after 2 weeks. The eRH of spores was monitored every month of storage.

The initial spores and spores stored for 18 months in a climatic chamber with controlled temperature of $15 \pm 1{ }^{\circ} \mathrm{C}$ were used for MC determination. About $100 \mathrm{mg}$ spores was dried at $85^{\circ} \mathrm{C}$ to a constant weight $(24 \mathrm{~h})$. Three replicates were performed. Moisture content 
(MC) was expressed as the percentage mass fraction of water of total spore mass according to the equation: $[(\mathrm{FW}-\mathrm{DW}) / \mathrm{FW}] \times 100$.

\section{Statistical analysis}

The spore germination and prothallus developmental data were shown as the mean \pm standard deviation of three or two independent replicates, representing 16 fields of view through a microscope per replicate. Results were evaluated by means of single-factor analysis of variance (ANOVA) and Fisher's Least Significant Difference Test (LSD) using Statgraphics Plus software. Significance was stated at $P<0.05$.

\section{Results}

\section{Germination and development of freshly collected spores}

After $28 \mathrm{~h}$ post-sowing, all freshly collected spores of $O$. regalis had germinated on the film of water (Fig. 1a-d). Imbibed spores were green inside and rich in lipid droplets (Fig. 1a). Their chlorophyll autofluoresced red, and their spore coats blue in response to blue-violet light (Fig. 1b). This was the first sign of spore viability and their willingness to germinate. The first visual sign that the spores were about to germinate was the rupture of the spore coat and the appearance of a rhizoidal cell (Fig. 1c). The first division of this spore cell was unequal, giving rise to a small cell that differentiated to form a rhizoid and a larger cell that occupied much of the spore volume. Control spores germinated quickly and evenly. After $28 \mathrm{~h}$ postsowing, all spores germinated (Fig. 1d). For a short time following the first cell division of the spore, both protonemal and rhizoidal cells contained chloroplasts (Fig. 1d).

The first division of the protonemal cell was almost equal and transverse to the polar axis of the germinated spore (Fig. 1e). It occurred simultaneously with the elongation of the rhizoidal cell. The second division was parallel to its axis (Fig. 1e). In contrast to the protonemal cells, the elongated rhizoid cell did not divide and contained few chloroplasts (Fig. 1f).

Next, several divisions of protonemal cells led to the formation of a young prothallus (Fig. 1g). The cells of gametophytes contained abundant chloroplasts and lipid droplets (Fig. 1h). The gametophytes formed more than one rhizoid per 8 days of growth (Fig. 1i). After 16 days, most rhizoids lacked chloroplasts (Fig. 1j) and gametophytes started to form a meristematic zone (Fig. 1k). Finally, at 2 months, gametophytes reached maturity.

\section{The spore moisture content in $\boldsymbol{O}$. regalis}

The eRH of freshly harvested $O$. regalis spores which were gradually released from sporangia, decreased rapidly from 69.8 to $48.6 \%$ during 2 days of storage at ambient room conditions $\left(24 \pm 5{ }^{\circ} \mathrm{C}\right.$; RH 45-80 \%) (Table 1). The water content in those spores amounted to $7.5 \%$. The spores exhibited clear responsivity to the relative humidity of storage air, and the MC during storage was decreasing fast until equilibrium has been reached. In a climatic chamber $\left(25 \pm 1{ }^{\circ} \mathrm{C}\right.$; RH $\left.42.0 \pm 2 \%\right)$, the eRH and MC of spores stored for 2 weeks in open Petri dishes dropped to 41 and $6.6 \%$, respectively. When the spores were stored at temperature of $25 \pm 1{ }^{\circ} \mathrm{C}$ and $\mathrm{RH}$ of $18.0 \pm 2 \%$, both studied parameters decreased from 48.6 and $7.5 \%$ to 18.5 and $4.6 \%$, respectively. After equilibration, spore moisture remained at almost constant level until the end of storage period (i.e. 18 months).

\section{The effect of moisture content and storage temperatures on spore vitality}

The total germination of freshly released $O$. regalis spores at the original moisture content $(7.5 \%)$ was $99.9 \%$, and it was equal to germinability of spores desiccated for 2 weeks under relative humidity of storage air (Table 2). The spores germinated within $28 \mathrm{~h}$ (Fig. 2), and the germination was uniform (Fig. 1c, d).

Spores kept at $15^{\circ} \mathrm{C}$ for 18 months differed in their ability to germinate depending on MC (Table 2). The germination of spores was complete (nearly $100 \%$ ) until month 8 of their storage. Germinability of spores in which the MC amounted to $6.6 \%$ decreased gradually between months $8(98.5 \%$ ) and 16 (to $71.4 \%$ ) of spore storage, reaching $20.1 \%$ by the end of month 18 . Spores of water content $4.5 \%$ exhibited more than $90 \%$ viability until month 16 of their storage. Significant decrease in germination capacity of the spores at months 17 and 18 (to $81.3 \%$ and 74.3, respectively) was observed (Table 2).

Variation in the timing of $O$. regalis spore germination was well noticeable when the spores were stored at $15^{\circ} \mathrm{C}$ (Fig. 2). The time required for spore germination increased with the age of the spores, ranging from $28 \mathrm{~h}$ to 10 days. After month 8 of storage, the period between water imbibition and spore germination increased rapidly, reaching a maximum of 10 days following months $17-18$ of storage.

When spores were stored at $15{ }^{\circ} \mathrm{C}$, the higher moisture content in spores $(\mathrm{MC}=6.6 \%$ ) caused faster reduction in the formation of gametophytes (Table 2). At month 10, almost $84 \%$ of those spores germinated, but more than $30 \%$ of them did not develop into gametophytes. For spores with lower moisture content $(\mathrm{MC}=4.5 \%)$, the $30 \%$ reduction in the ability of gametophytes development 

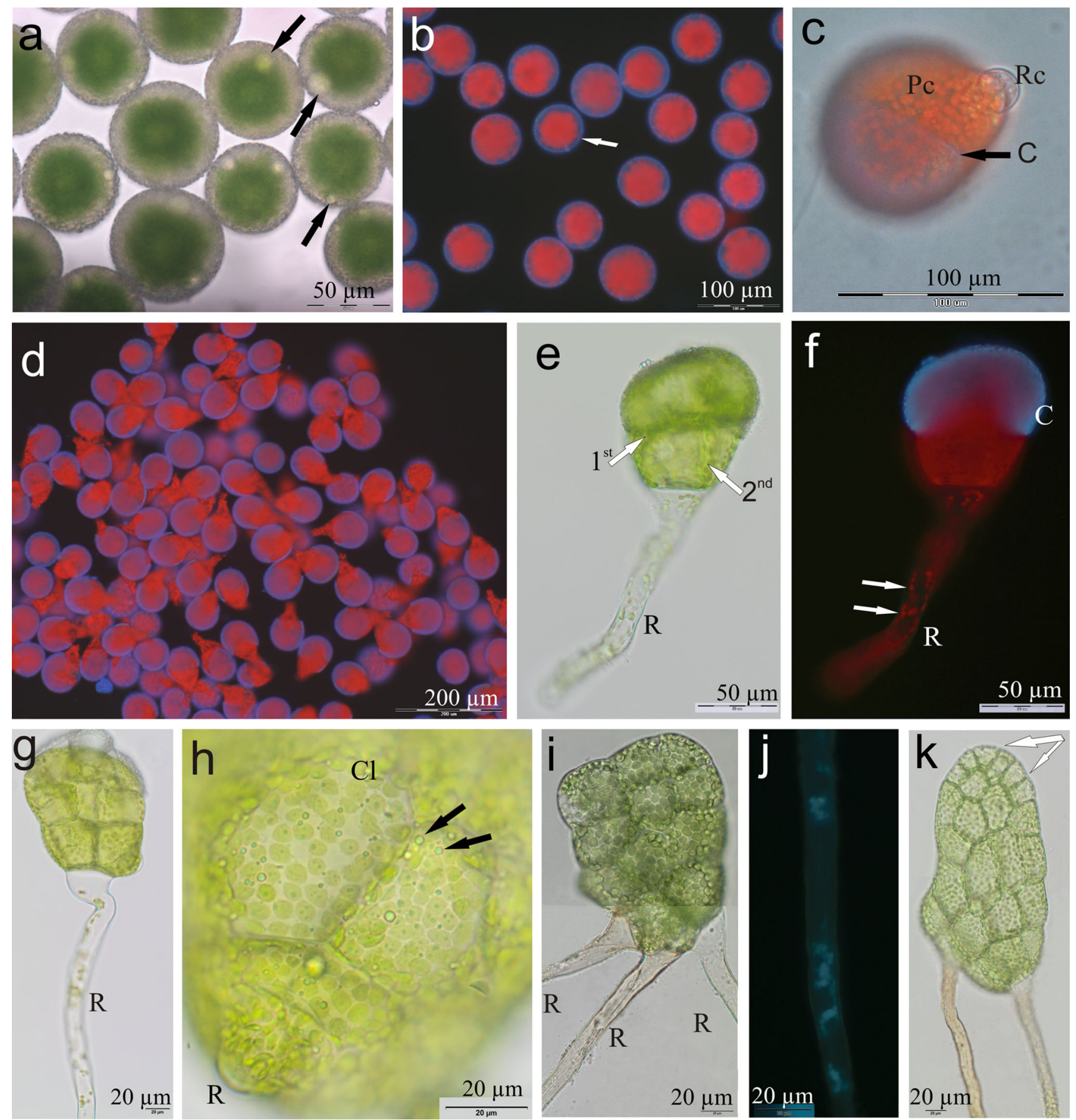

Fig. 1 Germination and development (on water) of freshly collected chlorophyllous spores of Osmunda regalis. a Swollen spores after 1-day imbibition (arrows lipid droplets), b blue autofluorescence of spore coat (arrow) and red autofluorescence of chlorophyll after 1-day imbibition induced by blue-violet light (BV filter: 400-440 nm) under epifluorescence microscope, $\mathbf{c}$ ruptured spore coat and the appearance of rhizoidal and protonemal cells; $28 \mathrm{~h}$ after sowing, $\mathbf{d}$ total spore germination, e prothallus consisting of protonemal cells after the first two divisions (arrows) and an elongated rhizoid; 3 days after sowing in white light, $\mathbf{f}$ view of the prothallus under blue-violet light - the chlorophyll autofluorescens red within chloroplasts (arrows), g a

multicellular gametophyte with elongated rhizoid; 5 days after sowing, h part of gametophyte with cells containing abundant chloroplasts and lipid droplets (arrows); 6 days after sowing, i young gametophyte with three rhizoids; 8 days after sowing, $\mathbf{j}$ view of rhizoid of young gametophyte under blue-violet light-note the lack of red autofluorescence of chlorophyll; 16 days after sowing, $\mathbf{k}$ initiation of gametophyte meristematic zone formation-distal marginal cells following several anticlinal divisions (arrows); 16 days after sowing. $C$ spore coat, $C l$ chloroplast, $R c$ Rhizoidal cell, $P c$ Protonemal cell, $R$ rhizoid 
Table 2 Influence of moisture content (MC) and storage conditions on percentage $O$. regalis spores capable of germinating (germination) and developing into normal gametophytes (development)

\begin{tabular}{|c|c|c|c|c|c|}
\hline \multirow[t]{4}{*}{ Storage time (months) } & \multicolumn{5}{|c|}{ Storage conditions } \\
\hline & \multicolumn{4}{|c|}{$15 \pm 1{ }^{\circ} \mathrm{C} ; \mathrm{RH}=18 \pm 2 \%$} & \multirow{3}{*}{$\begin{array}{l}-196{ }^{\circ} \mathrm{C} \\
\mathrm{MC}=6.6 \pm 0.05 \% \\
\text { Germination }=\text { development }\end{array}$} \\
\hline & \multicolumn{2}{|c|}{$\begin{array}{l}\text { In a tightly closed vials (initial } \\
\mathrm{MC}=6.6 \pm 0.05 \% \text { ) }\end{array}$} & \multicolumn{2}{|c|}{$\begin{array}{l}\text { In open Petri dishes (initial } \\
\mathrm{MC}=4.6 \pm 0.03 \% \text { ) }\end{array}$} & \\
\hline & Germination & Development & Germination & Development & \\
\hline Control & $99.9 \pm 0.1 \mathrm{a}$ & $99.9 \pm 0.1 \mathrm{a}$ & $99.9 \pm 0.1 \mathrm{a}$ & $99.9 \pm 0.1 \mathrm{a}$ & - \\
\hline 4 & $99.9 \pm 0.1 \mathrm{a}$ & $99.9 \pm 0.1 \mathrm{a}$ & $99.9 \pm 0.1 \mathrm{a}$ & $99.9 \pm 0.1 \mathrm{a}$ & $99.9 \pm 0.1 \mathrm{a}$ \\
\hline 8 & $98.5 \pm 0.7 \mathrm{ab}$ & $92.5 \pm 0.1 \mathrm{~b}$ & $98.6 \pm 0.1 \mathrm{a}$ & $98.6 \pm 0.1 \mathrm{a}$ & - \\
\hline 10 & $83.7 \pm 2.9 \mathrm{~b}$ & $51.9 \pm 2.1 \mathrm{c}$ & $98.1 \pm 1.1 \mathrm{a}$ & $98.1 \pm 1.1 \mathrm{a}$ & $99.9 \pm 0.1 \mathrm{a}$ \\
\hline 11 & $83.6 \pm 5.9 b$ & $51.6 \pm 4.0 \mathrm{c}$ & $93.2 \pm 3.4 \mathrm{~b}$ & $93.2 \pm 3.4 \mathrm{~b}$ & - \\
\hline 13 & $75.9 \pm 1.9 \mathrm{c}$ & $33.2 \pm 2.5 \mathrm{~d}$ & $93.0 \pm 3.5 \mathrm{~b}$ & $83.4 \pm 2.8 \mathrm{c}$ & $99.9 \pm 0.1 \mathrm{a}$ \\
\hline 16 & $71.4 \pm 1.7 \mathrm{c}$ & $24.8 \pm 2.6 \mathrm{e}$ & $92.8 \pm 4.7 \mathrm{~b}$ & $64.6 \pm 1.9 \mathrm{~d}$ & - \\
\hline 17 & $23.6 \pm 0.5 \mathrm{~d}$ & $2.9 \pm 0.6 \mathrm{f}$ & $81.3 \pm 4.8 \mathrm{c}$ & $41.9 \pm 3.9 \mathrm{e}$ & - \\
\hline 18 & $20.1 \pm 0.8 \mathrm{~d}$ & $0.8 \pm 0.1 \mathrm{~g}$ & $74.3 \pm 2.5 \mathrm{~d}$ & $33.2 \pm 1.9 \mathrm{f}$ & $99.9 \pm 0.1 \mathrm{a}$ \\
\hline 84 & - & - & - & - & $99.9 \pm 0.1 \mathrm{a}$ \\
\hline
\end{tabular}

Values represent mean \pm standard deviation of three independent replicates, 16 fields of view through the microscope per replicate

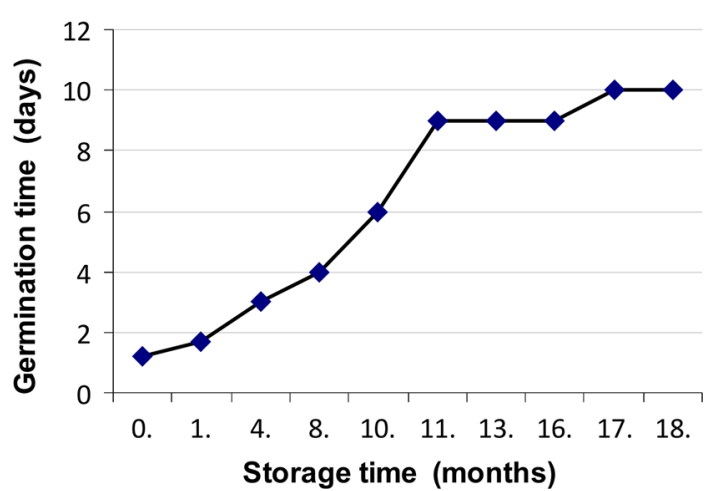

Fig. 2 Variation in the timing of $O$. regalis spore germination stored at $15{ }^{\circ} \mathrm{C}$

was observed after 16 months. At the end of storage period, $33.2 \%$ of spores with lower MC was still capable of forming gametophytes, while it was almost totally stopped by the end of month 17 in the second type of spores.

Long-term spore storage at temperature of $15{ }^{\circ} \mathrm{C}$ contributed to disturbances in their germination. Spores with $\mathrm{MC}=6.6 \%$ and $\mathrm{MC}=4.5 \%$, did not display uniform germination since months 10 and 16 of storage, respectively. Instead, all the following stages were visible simultaneously: imbibed spores (1), recently germinated spores with ruptured coat (2) and multicellular young gametophytes (3) (Fig. 3a, b). The germinating spores developed into young prothallia in the next few days (Fig. 3c). Some prothalli showed disturbances in rhizoid formation but their later growth was normal. Development of gametophytes from spores incapable of fast germination (no 1. on the Fig. 3a, b) was arrested after the first (Fig. 3d) or second (Fig. 3e) or fourth cell division (Fig. 3f). In abnormally growing $2-5$-celled prothalli, chloroplasts were very scant (Fig. 3d-f).

When spores with higher moisture content ( $\mathrm{MC}=6.6 \%$ ) were stored in $\mathrm{LN}$, their survival was high $(99.9 \%)$ and the time required for germination was constant (Table 2; Fig. 3g). Germinability and germination time did not change for the whole period of storage, i.e. 7 years. Growth of gametophytes obtained from cryostored spores was normal (Fig. 3h). An apical cytoplasmic cap containing dense cytoplasm was clearly visible in actively growing rhizoids (Fig. 3h). All gametophytes developed normally (Fig. 3i), attained maturity and finally were able to reproduce sexually.

\section{Discussion}

\section{Desiccation tolerance of green spores}

Green spores of ferns are more tolerant of desiccation than was originally thought (Raghavan 1989). Pence (2000) discovered that spores of $O$. regalis are able to survive exposure to low relative humidity (below $20 \%$ overnight). Encapsulated spores survived $18 \mathrm{~h}$ of osmotic dehydration and $4 \mathrm{~h}$ of air desiccation. However, the moisture status of the spores was not assessed by her. Recently, Li and Shi (2014) showed for the first time the changes in water 

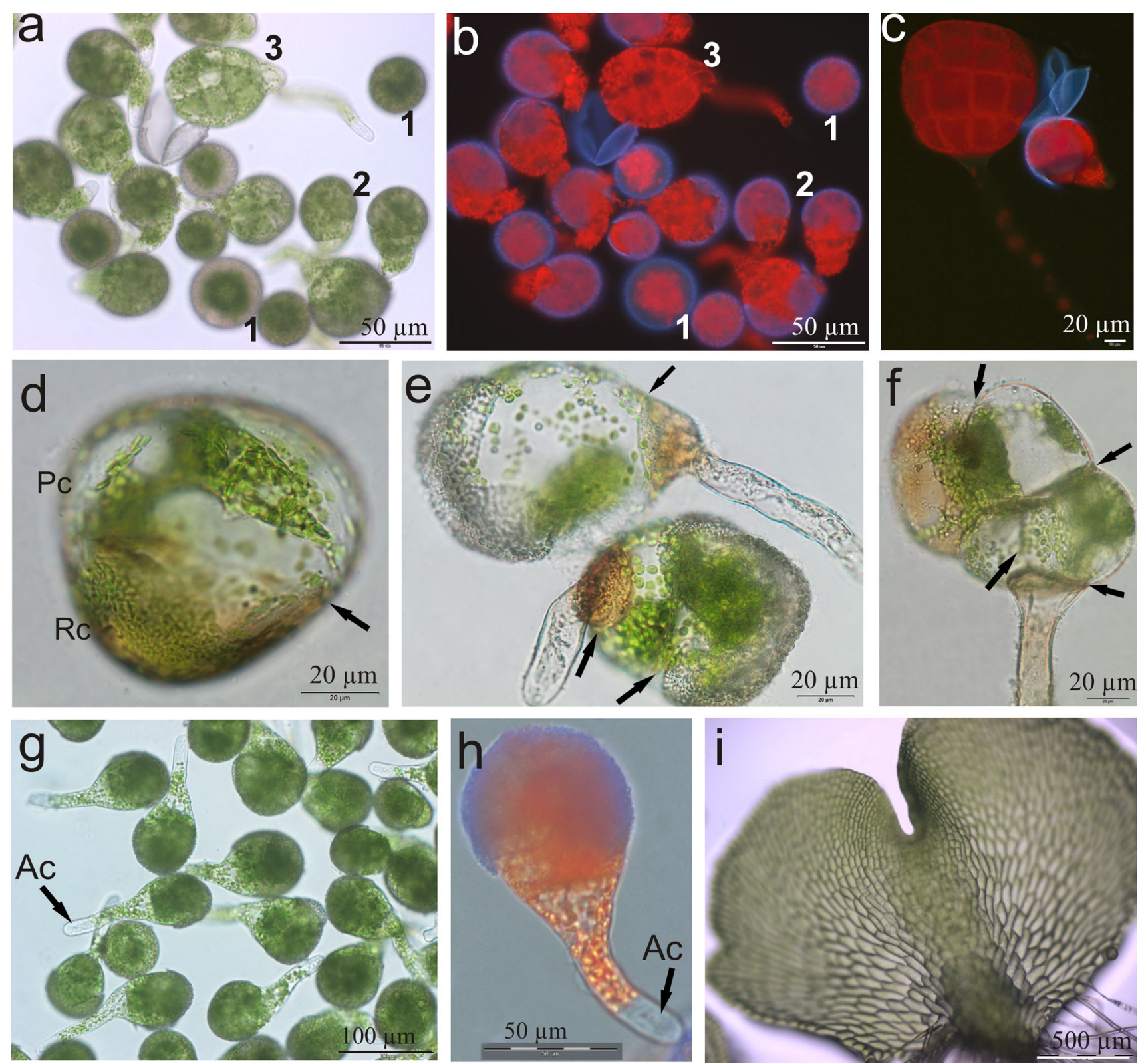

Fig. 3 Germination and development (on water) of Osmunda regalis spores stored under two different temperature regimes: $15^{\circ} \mathrm{C}(\mathbf{a}-\mathbf{f})$, $-196{ }^{\circ} \mathrm{C}(\mathbf{g}-\mathbf{i})$. a Gradual germination of spores of moisture content $4.5 \%$, after 16 months (1 imbibed spores; 2 recently germinated spore; 3 multicellular gametophyte); viewed after 7 days imbibition in white light and b in blue-violet light, c normally developed multicellular gametophyte (no. 3) and recently germinated spore (no. 2) after 10 days post-sowing in blue-violet light, $\mathbf{d}$ spore after the first atypical division (arrow), e abnormally growing 2-3-celled prothalli

content in green spores during desiccation process. The water content in the fresh spores of $O$. japonica was $11.2 \%$, and it decreased rapidly to 6.6 and $4.4 \%$ after desiccation by silica gel for 12 and $48 \mathrm{~h}$, respectively ( $\mathrm{Li}$ and Shi 2015). The desiccation level of spores (from 19.4 to $4.8 \% \mathrm{MC}$ ) was also modified by equilibrating at possessing few chloroplasts, $\mathbf{f}$ decayed, 5-celled prothallus at 10 days post-sowing, $\mathbf{g}$ mass production of 2-3-celled prothalli from spores thawed after 6 years storage under liquid nitrogen; viewed after $28 \mathrm{~h}$ post-sowing, $\mathbf{h}$ a normally developed 3-celled prothallus rich in chloroplasts; viewed after $28 \mathrm{~h}$; mixture of white and blue-violet light, i a 2-month-old cordate gametophyte derived from a cryo-stored spore. Ac apical cytoplasmic cap, $P c$ Protonemal cell, $R$ rhizoid, $R c$ rhizoidal cell, arrow cell wall

different RH levels (from 96 to $10 \%$ ) using saturated salt solutions for a week ( $\mathrm{Li}$ and Shi 2015). Their studies and ours demonstrated that an internal relative humidity of green spores, similar to that of non-green (Ballesteros and Walters 2007b; Ballesteros et al. 2012), can be easily manipulated by equilibration at different relative humidity 
values. The critical MC for mature spores of $O$. japonica was determined to be about 4.8-6.6\% (Li and Shi 2015). For comparison, our study revealed that the spore germination of $O$. regalis $(99.9 \%)$ was not affected even by desiccation to $4.6 \% \mathrm{MC}(\mathrm{eRH}=18.5 \%)$. According to Lebkuecher (1997) the chlorophyllous spores of Equisetum hyemale can be desiccated almost completely following storage at $25{ }^{\circ} \mathrm{C}$ and $2 \% \mathrm{RH}$. Ninety percent of the spores survived that extreme, however, not longer than 1-weeklong, desiccation to $4 \%$ relative water content. Thus, the studies show that the moisture content in green spores could be comparable to those described in the non-green spores of Polypodium vulgare $(6.5 \%)$ (Smith and Robinson 1975), Alsophila spinulosa (7.45\%), A. gigantea (5.85\%) and A. podophylla (5.95\%) (Li et al. 2010). By comparison, for recalcitrant seeds, the critical MC values below which dehydration injury occurs waver between 32 and $50 \%$ (Pritchard et al. 1995). For pollen, like orthodox seeds, critical moisture level waver between 5 and $10 \%$ (Metz et al. 2000). Although an intolerance of desiccation is one of the crucial factors suspected of causing the rapid loss of viability in recalcitrant seeds (Pritchard et al. 1995), this factor seems not to be directly responsible for the decline in the ability to germinate of green spores.

\section{Reduction of storage temperature is a first step towards spore longevity}

Temperature is one of the crucial factors affecting the viability of fern spores during storage. Its reduction leads to extension of the spore longevity. The effect of various temperatures on $O$. regalis spore germination and developmental behaviour was commenced at ambient temperature $\left(25^{\circ} \mathrm{C}\right)$, progressing through $15,2-6,-20$ or -25 , $-40,-80{ }^{\circ} \mathrm{C}$ and finally $-196{ }^{\circ} \mathrm{C}$ (LN) (Stokey 1951; Pence 2000; Ballesteros et al. 2011; Magrini and Scoppola 2012).

The retention of vitality of $O$. regalis spores increased along with decreasing storage temperature. An ambient temperature is not effective for the long-term preservation of green spores. Magrini and Scoppola (2012) showed that only up to $5.9 \%$ of $O$. regalis spores survived 1 month of storage at $25{ }^{\circ} \mathrm{C}$. In contradiction, the studies of Ballesteros et al. (2011) and ours (data not shown) demonstrated that spores of this species retained their capacity to germinate even 3 months at $25{ }^{\circ} \mathrm{C}$, but lost it completely during the next month. Our study indicated that the germination of spores was, independent of their MC, complete (nearly $100 \%$ ), uniform and rapid until month 8 of storage at $15^{\circ} \mathrm{C}$. Several sources report that a very small part of green spores can survive longer than 2 years at temperatures ranging from 2 to $6{ }^{\circ} \mathrm{C}$. The viability of fully hydrated spores of $O$. regalis was about $10 \%$ after
28 months of storage at $5{ }^{\circ} \mathrm{C}$ (Magrini and Scoppola 2012). Stokey (1951) demonstrated that the survival of $O$. regalis and $O$. claytoniana spores maintained for more than 3.5 years at $2-6{ }^{\circ} \mathrm{C}$ was about $4-5$ and $1 \%$, respectively. However, other papers reported that viability of $O$. regalis spores stored at $4{ }^{\circ} \mathrm{C}$ seriously began to decline after about 6 months, and that after 12 months, only $2 \%$ spores germinated (Ballesteros et al. 2011). Temperatures ranging from -20 to $-25^{\circ} \mathrm{C}$ were beneficial for preserving $O$. regalis spore germination and capacity for gametophyte development for a period of 24-28 months (Ballesteros et al. 2011; Magrini and Scoppola 2012). However, a $20-50 \%$ reduction in viability was reported at that time. In general, temperatures as low as $-25{ }^{\circ} \mathrm{C}$ are insufficient to prevent deterioration of spore survival effectively because of triacylglycerols crystallization (Ballesteros and Walters 2007a).

The life span of $O$. regalis spores could be effectively prolonged by storing at temperatures between -80 and $-196{ }^{\circ} \mathrm{C}$ (Ballesteros et al. 2011). In this case, there was no loss of viability and vigor of over a 2 -year-long period of storage. Unlike the spores of $O$. regalis, the spores of Equisetum ramosissimum were short-lived even in LN (Ballesteros et al. 2011). After month 24 of cryostorage, a significant decline in viability of those spores was noticed. For non-green spores of Alsophila spinulosa and $A$. gigantea, storage in LN for 1 year resulted in 10-20\% loss of their viability, and in complete loss of it for A. podophylla (Li et al. 2010). More than 10-50\% reduction in survival of $O$. japonica spores after 1 year of LN storage was observed by $\mathrm{Li}$ and Shi (2015). These authors demonstrated that the level of maturity and desiccation process can have an impact on the viability of green spores during LN storage. The viability of mature spores was always higher than those of post-mature spores. Moreover, their study showed that the mature spores can tolerate LN freezing independently of the desiccation process ( $\mathrm{Li}$ and Shi 2015). Our results seems to be consistent with their achievements. When mature and fully capable of germinating spores of $O$. regalis $(\mathrm{eRH}=41 \%$; $\mathrm{MC}=6.6 \%$ ) were used for cryostorage, their survival remained at $100 \%$ for at least 7 years. It indicates that $\mathrm{LN}$ is the best option for the long-term storage of $O$. regalis spores. Furthermore, the spores may be put into LN immediately after harvest and without any additional treatment, thus making the conservation of genetic material, and hence biodiversity of this species, very simple, quick and safe.

\section{Effects of increasing age of spores}

Factors affecting viability of spores, such as genotype, age, temperature, storage humidity and moisture content (Gabriel y Galán and Prada 2011), lead to an increase in delay in 
germination, a decrease in the rate of germination, and a decline in germination ability (Stokey 1951; Smith and Robinson 1975; Beri and Bir 1993; Magrini et al. 2010; Ballesteros et al. 2011). These factors also contribute to an increase in the proportion of abnormal gametophytes, a postponement of early gametophyte development (Camloh 1999; Ballesteros et al. 2011) or disruption of gametophyte morphology (Smith and Robinson 1975; Li et al. 2010). An understanding of spore longevity and dynamics of vitality deterioration is crucial to the investigation of mechanisms of spore aging. According to our results, the green spores of $O$. regalis and the storage temperature as high as $15{ }^{\circ} \mathrm{C}$ seems to be the best for that purpose. The deterioration of the spore germination, maintained with $6.6(\mathrm{eRH}=41 \%)$ and $4.6 \% \mathrm{MC}(\mathrm{eRH}=18.5 \%)$, proceeds smoothly within a year and a half of storage, starting with month 10 and 11 , respectively. In contrast to $O$. regalis green spores, the visible decline in germination in non-green spores of Polypodium vulgare was observed after about 2 years of storage at $4{ }^{\circ} \mathrm{C}$ (Smith and Robinson 1975). A clearly noticeable deterioration in the vigor of $O$. regalis spores maintained with $6.6 \% \mathrm{MC}$ occurred by the end of month 8 of storage at $15{ }^{\circ} \mathrm{C}$. For spores stored with $4.6 \% \mathrm{MC}$, significant disturbances in the capacity for gametophyte development were postponed for 3 months, however, still more than $90 \%$ of normal gametophytes was obtained. By comparison, only $25 \%$ of germinating spores of $O$. regalis developed into gametophytes after 12 months of storage at $4{ }^{\circ} \mathrm{C}$ and about $65 \% \mathrm{RH}$ (Ballesteros et al. 2011). The studies reveal that the capacity for germination and normal gametophyte development by spores stored at temperature higher than zero are directly correlated with their MC.

We also found that the time required for spore germination increased with the age of the spores, ranging from $28 \mathrm{~h}$ in fresh spores to $9-10$ days in spores stored for more than 11 months at $15{ }^{\circ} \mathrm{C}$. These results are in agreement with those obtained by Stokey (1951), Magrini et al. (2010), Ballesteros et al. (2011) and Beri and Bir (1993) who also showed a significant lengthening of germination time in both green $(O$. regalis) and non-green (Pteris vittata) spores. The 34- and 130- and 150-day-old spores of $O$. regalis germinated in 4 days and 7 days and 20 days, respectively (Stokey 1951). Time to $50 \%$ of maximum germination (T50) increased to 15 days for $O$. regalis spores stored for 12 months at $4{ }^{\circ} \mathrm{C}$ and about $65 \%$ RH (Ballesteros et al. 2011). According to Magrini et al. (2010), the time required for the germination of 5 -year-old spores of this species, stored in closed polyethylene bags with an internal RH equal to $52 \%$, was 20 days. After 17 years of storage, less than $1 \%$ of these spores germinated within 30 days and died shortly after germination (Magrini et al. 2010). Our data showed that most of the germinating aging spores were able only to complete the first $2-4$ cell divisions (Fig. $3 d-f$ ). Sometimes, the 3-5-celled prothalli had normally developed rhizoids, but these were not capable of further divisions and gametophyte formation. Some authors state that the loss of viability of green spores may be attributed to rapid changes in the moisture content (Beri and Bir 1993) and a failure to recover photosynthetic activity following desiccation (Lebkuecher 1997). Our study showed that although the spore humidity was maintained at a constant level during 18 months of storage (ca. $4.5 \% \mathrm{MC}$ ), the differences in spore vitality were clearly visible. It may suggests that the changes in desiccation level per se during storage of spores were not a direct cause of their deterioration. It is more probable that the spore MC was still enough to maintain a high rate of respiration. The degree of respiratory activity could be the main limiting factor in chlorophyllous spores that are constantly physiologically active (Hauke 1963; Lloyd and Klekowski 1970). In non-germinated spores, soluble sugars, free amino acids, storage proteins and lipids, as well as starch grains in chloroplasts, are present in significant quantities in order to satisfy demands for energy and substrates for germination (Gantt and Arnott 1965; DeMaggio et al. 1980). The high metabolic activity during germination causes the depletion of storage reserves what has been demonstrated for green spores of Onoclea sensibilis (DeMaggio et al. 1980) and non-green spores of Pteris vittata (Beri and Bir 1993). And as the storage compounds become totally depleted, the spores become nonviable (Lloyd and Klekowski 1970). The resulting deficiency in respiratory substrates leads to an irreversible loss of membrane permeability (Kato 1976), many biochemical impairments (i.e. inactivation of various enzymes and growth substances), or genetic disruption, as has been studied for aging seeds (Murthy et al. 2003). The delay in germination of seeds is thought to reflect the time required for repair of damaged membranes and for a potentially costly reallocation of internal resources during rehydration (Berjak and Villiers 1972). Therefore, the aged seeds which germinate may develop after a delay into normal or weak seedlings. Similarly, in aging spores, recovery of gametophytes can be incomplete, and the accumulation of defects may eventually lead to death of cell/spore.

\section{Conclusion}

We conclude that storage conditions for $O$. regalis green spores can be optimized not only by lowering the temperature of spore maintenance, but also by controlling their water content. It is possible to achieve full arrestment of aging process in spores of $O$. regalis for at least 7 years 
using ultra-low temperature of LN. Thus, LN is the most appropriate for the conservation of $O$. regalis genetic diversity in ex situ conditions.

On the other hand, $O$. regalis spores, because of their unicellular structure and rapid loss of viability, can probably be a better object than seeds for investigating the deterioration during aging. The spores themselves could be considered as a valuable material for fundamental research into structural, biochemical and molecular mechanism of the process of aging. Knowledge of the dynamics of $O$. regalis spore deterioration, that has been provided with this work, is an important first step in such studies.

Author contribution statement The authors have made the following declarations regarding their contributions: Conceived and designed the experiments: AM. Performed the experiments: KT, DM, MN, AM. Contributed to the writing of the manuscript: AM, KT, JJR.

\section{Compliance with ethical standards}

Conflict of interest The authors declare that they have no conflict of interest.

Open Access This article is distributed under the terms of the Creative Commons Attribution 4.0 International License (http://crea tivecommons.org/licenses/by/4.0/), which permits unrestricted use, distribution, and reproduction in any medium, provided you give appropriate credit to the original author(s) and the source, provide a link to the Creative Commons license, and indicate if changes were made.

\section{References}

Ballesteros D (2011) Conservation of fern spores. In: Fernández H, Kumar A, Revilla MA (eds) Working with ferns: issues and applications. Springer, New York, pp 165-172

Ballesteros D, Walters C (2007a) Calorimetric properties of water and triacylglycerols in fern spores relating to storage at cryogenic temperatures. Cryobiology 55:1-9

Ballesteros D, Walters C (2007b) Water properties in fern spores: sorption characteristics relating to water affinity, glassy states and storage stability. J Exp Bot 58:1185-1196

Ballesteros D, Estrelles E, Walters C, Ibars AM (2011) Effect of storage temperature on green spore longevity for the ferns Equisetum ramosissimum and Osmunda regalis. Cryo Lett 32:89-98

Ballesteros D, Estrelles E, Walters C, Ibars AM (2012) Effect of temperature and desiccation on ex situ conservation of non-green fern spores. Am J Bot 99:721-729

Barnicoat H, Cripps R, Kendon J, Sarasan V (2011) Conservation in vitro of rare and threatened ferns-case studies of biodiversity hotspot and island species. In Vitro Cell Dev Biol-Plant 47:37-45

Beri A, Bir SS (1993) Germination of stored spores of Pteris vittata L. Am Fern J 83:73-78

Berjak P, Villiers TA (1972) Ageing in plant embryos. II. Ageinduced damage and its repair during early germination. New Phytol 71:135-144
Camloh M (1999) Spore age and sterilization affects germination and early gametophyte development of Platycerium bifurcatum. Am Fern J 89:124-132

DeMaggio AE, Greene C, Stetler D (1980) Biochemistry of fern spore germination. Glyoxylate and glycolate cycle activity in Onoclea sensibilis L. Plant Physiol 66:922-924

Gabriel y Galán JM, Prada C (2011) Pteridophyte spores viability. In: Fernández H, Kumar A, Revilla MA (eds) Working with ferns: issues and applications. Springer, New York, pp 193-206

Gantt E, Arnott HJ (1965) Spore germination and development of the young gametophyte of the Ostrich fern (Matteuccia struthiopteris). Amer J Bot 52:82-94

Gupta S, Hore M, Biswas S (2013) An overview of the study of soil spore bank of ferns: need for suitable exploitation in India. Proc Natl Acad Sci, India, Sect B Biol Sci, doi:10.1007/s40011-0130245-z

Hauke RL (1963) A taxonomic monograph of the genus Equisetum, subgenus Hippochaete. Beih Nova Hedwigia 8:1-123

Ibars AM, Estrelles E (2012) Recent developments in ex situ and in situ conservation of ferns. Fern Gaz 19:67-86

IUCN (2014) The IUCN red list of threatened species http://www. iucnredlist.org/details/164368/0 downloaded on 06 February 2015

Kato Y (1976) The effect of freezing and organic solvents on viability of chlorophyllous fern spores. Cytologia 41:387-393

Lebkuecher JG (1997) Desiccation-time limits of photosynthetic recovery in Equisetum hyemale (Equisetaceae) spores. Am J Bot 84:792-797

Li Y, Shi L (2014) Effect of desiccation level and storage temperature on green spore viability of Osmunda japonica. Cryobiology 68:446-450

Li Y, Shi L (2015) Effect of maturity level and desiccation process on liquid nitrogen storage of green spores of Osmunda japonica. Plant Cell Tiss Org Cult 120:531-538

Li Y, Zhang YL, Jiang CD, Wang T, Wang Q, Shi L (2010) Effect of storage temperature on spore viability and early gametophyte development of three vulnerable species of Alsophila (Cyatheaceae). Aust J Bot 58:89-96

Lloyd RME, Klekowski J (1970) Spore germination and viability in Pteridophyta: evolutionary significance of chlorophyllous spores. Biotropica 2:129-137

Magrini S, Scoppola A (2012) First results from conservation studies of chlorophyllous spores of the Royal fern (Osmunda regalis, Osmundaceae). Cryobiology 64:65-69

Magrini S, Olmati G, Onofri S, Scoppola A (2010) Recovery of viable germplasm from herbarium specimens of Osmunda regalis L. Am Fern J 100:159-166

Metz C, Nerd A, Mizrahi Y (2000) Viability of pollen of two fruit crop cacti of the genus Hylocereus is affected by temperature and duration of storage. HortScience 35:22-24

Mikuła A, Jata K, Rybczyński JJ (2009) Cryopreservation strategies for Cyathea australis (R. BR.) DOMIN. Cryo Lett 30:429-439

Mikuła A, Makowski D, Walters C, Rybczyński JJ (2011) Exploration of cryo-methods to preserve tree and herbaceous fern gametophytes. In: Fernández H, Kumar A, Revilla MA (eds) Working with ferns: issues and applications. Springer, New York, pp 173-192

Mirek Z, Zarzycki K, Wojewoda W, Szeląg Z (2006) Red list of plants and fungi in Poland. In: W Szafer (ed) Institute of Botany, Polish Academy of Sciences. Cracow, pp 1-99

Morini S (2000) In vitro culture of Osmunda regalis fern. J Hortic Sci Biotech 75:31-34

Murthy UMN, Kumar PP, Sun WQ (2003) Mechanisms of seed ageing under different storage conditions for Vigna radiata (L.) Wilczek: lipid peroxidation, sugar hydrolysis, Maillard reactions 
and their relationship to glass state transition. J Exp Bot 54:1057-1067

Pence VC (2000) Survival of chlorophyllous and non-chlorophyllous fern spores through exposure to liquid nitrogen. Am Fern J 90:119-126

Pence VC (2008a) Cryopreservation of bryophytes and ferns. In: Reed BM (ed) Plant cryopreservation: a practical guide. Springer, New York, pp 117-140

Pence VC (2008b) Ex situ conservation of ferns and lycophytes: approaches and techniques. In: Ranker TA, Haufler $\mathrm{CH}$ (eds) Biology and evolution of ferns and lycophytes. Cambridge University Press, Cambridge, UK, pp 284-300

Pritchard HW, Tompsett PB, Manger K, Smidt WJ (1995) The effect of moisture content on the low temperature responses of Araucaria hunsteinii seed and embryos. Ann Bot 76:79-88

Probert RJ, Manger KR, Adams J (2003) Non-destructive measurement of seed moisture. In: Smith RD, Dickie JB, Linington SH, Pritchard HW, Probert RJ (eds) Seed conservation: turning science into practice. Royal Botanic Gardens, Kew, pp 367-387
Quintanilla LG, Amigo J, Pangua E, Pajaron S (2002) Effect of storage method on spore viability in five globally threatened fern species. Ann Bot 90:461-467

Raghavan V (1989) Physiology of spore germination. In: Raghavan V (ed) Developmental biology of fern gametophytes. Cambridge University Press, Cambridge, UK, pp 27-53

Smith DL, Robinson PM (1975) The effect of spore age on germination and gametophyte development in Polypodium vulgare L. New Phytol 74:101-108

Soare LC (2008) In vitro development of gametophyte and sporophyte in several fern species. Not Bot Hort Agrobot Cluj 36:13-19

Stokey AG (1951) Duration of viability of spores of the Osmundaceae. Amer Fern J 41:111-115

Windham M, Wolf P, Ranker T (1986) Factors affecting prolonged spore viability in herbarium collections of three species of Pellaea. Am Fern J 76:141-148 